Proc. Estonian Acad. Sci. Biol. Ecol., 2003, 52, 3, 284-304

\title{
Establishment of new gammarid species in the eastern Gulf of Finland (Baltic Sea) and their effects on littoral communities
}

\author{
Nadya A. Berezina* and Vadim E. Panov \\ Zoological Institute of the Russian Academy of Sciences, Universitetskaya nab. 1, 199034 \\ St. Petersburg, Russia \\ Received 7 January 2003, in revised form 19 May 2003
}

\begin{abstract}
During the last ten years two new species of gammarids, Gmelinoides fasciatus (Stebb.) and Pontogammarus robustoides (Sars), invaded the Gulf of Finland. We studied the distribution and abundance of these species and their effects on littoral communities in the Neva estuary in 1998-2002. The study was performed in three types of habitats: Phragmites australis beds, exposed stone littoral, and Cladophora glomerata mats on stones. Feeding rates of the gammarids consuming filamentous algae and benthic invertebrates were estimated experimentally. Intensive consumption of plant food (Cladophora, roots and debris of Phragmites) by gammarids resulted in the production of faeces that increases organic matter availability for benthic detritivores. At the same time, gammarid predation resulted in a decrease of benthic invertebrates. The magnitude of the effects depended on the density of the established species and the type of habitat. In addition, an experimental study of interactions between $G$. fasciatus and P. robustoides revealed the existence of intraguild predation, which was the strongest in the case of $P$. robustoides.
\end{abstract}

Key words: bioinvasions, gammarids, Gmelinoides fasciatus, Pontogammarus robustoides, salinity tolerance, feeding, predation.

\section{INTRODUCTION}

Invasions of aquatic organisms mediated by human activities, including maritime transportation, construction of canals, intentional introductions, are a growing environmental issue worldwide (Leppäkoski \& Olenin, 2000). These invasions have resulted in global mixing of previously isolated biota and drastic alterations in aquatic communities, including decline in natural biodiversity of large marine and freshwater ecosystems. Patterns of amphipod invasions in Europe including the Baltic Sea basin are well known (Gasiunas, 1972; Van der Velde et al., 1999;

\footnotetext{
*Corresponding author, nber@zin.ru
} 
Jazdzewski \& Konopacka, 2000; Bij de Vaate et al., 2002), yet interactions with native species and impacts of established species on the environment are very poorly understood. It is known that environmental impacts of established invaders may be positive, neutral, or negative and depend on characteristics of a successful invader (Holdich et al., 1999; Westman, 2002). As for amphipods, these characteristics may include a larger body, faster growth, more aggressive behaviour, greater fecundity, or better tolerance of unfavourable abiotic factors and pollution than in native species (discussed by Mordukhai-Boltovskoi, 1960; Dennert, 1974; Dedju, 1980; Dick et al., 1999; Van der Velde et al., 1999; Berezina \& Panov, 2003). After the establishment of alien species, their populations increase and feeding habits may be the main mechanism for change in the invaded community (Nyström et al., 1999). In many cases an invader represents a new functional group in the community and differs substantially from native species in life cycles and feeding resources. These processes may contribute to the decline in native species or their exclusion by established alien species (Elton, 1958).

During the last decade some alien species of gammarids invaded the eastern Gulf of Finland (Neva estuary). The first newcomer was the Baikalian gammarid Gmelinoides fasciatus (Stebb.), found in the freshwater part of the Neva estuary in 1996 and in brackish-water reaches of the estuary in 1999 (Panov et al., 1999; Panov \& Berezina, 2002). The Ponto-Caspian gammarid Pontogammarus robustoides (Sars) is one of the most recent invaders in the Gulf of Finland. In 1999 it was first found in the southern part of Neva Bay (Orlova et al., 1999a; Panov et al., 2002).

We studied the distribution and abundance of the gammarids in Neva Bay and the inner part of the Neva estuary during 1998-2002 in order to estimate their possible effects on littoral communities. We hypothesized that the effects of established alien gammarids on littoral communities of the Neva estuary are positive and include enrichment of sediments with organic matter as a result of intensive foraging of gammarids on detritus and plant food. We also investigated whether interspecies predation on benthic invertebrates results in declining density and changing structure of the native invertebrate community and whether replacement of some species occurs under the impact of $P$. robustoides on G. fasciatus.

\section{MATERIAL AND METHODS \\ Description of the sites studied}

The study area was located in the coastal zone of the Russian part of the eastern Gulf of Finland $\left(59^{\circ} 45^{\prime}-60^{\circ} 25^{\prime} \mathrm{N}\right.$ latitude and $28^{\circ} 12^{\prime}-29^{\circ} 09^{\prime} \mathrm{E}$ longitude). This area includes the Neva estuary and Luga Bay. The Neva estuary consists of three main parts: Neva Bay, the inner and the outer estuary. The inner part of the estuary is separated from Neva Bay by a storm-surge barrier (Fig. 1). In 19982001 our studies were focused on the littoral zone (depths from 0.2 to $1.5 \mathrm{~m}$ ) of different parts of the Neva estuary (Fig. 1; stations 1,2, and 3). 


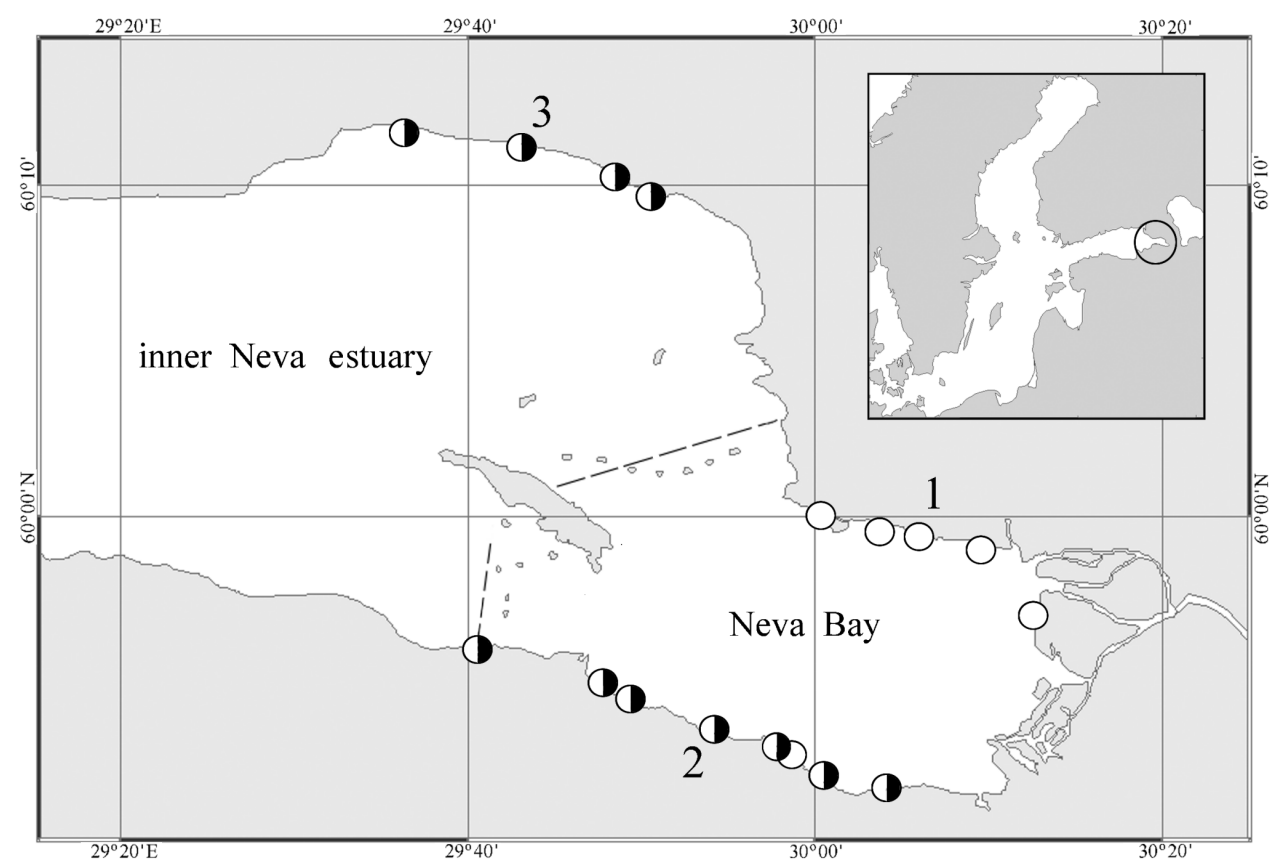

Fig. 1. Distribution of Gmelinoides fasciatus and Pontogammarus robustoides in the Neva estuary in 2002. Open circles indicate locations of $G$. fasciatus, partly filled circles indicate locations of coexisting species (G. fasciatus and P. robustoides). 1 - station 1 (Phragmites beds), 2 - station 2 (exposed stone littoral), and 3 - station 3 (exposed stone littoral with Cladophora mats). Dashed line indicates a storm-surge barrier. Circle on the inserted map of the Baltic Sea shows the studied area of the eastern Gulf of Finland.

Since the end of the last century, extensive macrophyte beds (mainly Phragmites australis, Scirpus lacustris, and Potamogeton pectinatus) have developed in the Neva Bay coastal zone during summer as a result of eutrophication. Locally they extend up to 600-700 $\mathrm{m}$ from the shoreline (Korelyakova, 1997; Panov et al., 2002). The development of macrophyte beds in the inner Neva estuary is limited by wave disturbance and salinity. In this part of the estuary the filamentous green algae (mainly Cladophora glomerata) proliferate on hard substrates. In the littoral zone of the Neva estuary coarse sand, gravel, and stones are typical bottom substrates. The studied stations are regarded as the three main types of habitats in the Neva estuary: Phragmites beds (station 1), exposed stone littoral (station 2), and Cladophora mats on stones (station 3).

During our sampling the salinity of shallow and surface water varied in the range 0.06-0.4 PSU in the freshwater part (Neva Bay) and 0.45-2.0 PSU in the inner part of the estuary. In the open part (depth $20 \mathrm{~m}$ ) of the inner estuary near the studied location the bottom water salinity ranged from 0.67 to $3.2 \mathrm{PSU}$. Oxygen saturation during daytime exceeded $80-90 \%$ in the littoral zone during 
the whole period of observations. The summer temperature averaged $19.5^{\circ} \mathrm{C}$ with a maximum of up to $27.5^{\circ} \mathrm{C}$ in July. In September the water temperature fell to $12-14^{\circ} \mathrm{C}$.

\section{Field surveys}

In the macrophyte beds quantitative sampling was carried out with a cylindrical $0.125 \mathrm{~m}^{2}$ corer (Panov \& Pavlov, 1986) in two replicates or a special tube with a sampling area of $0.03 \mathrm{~m}^{2}$ in three or four replicates. On hard substrates quantitative samples were collected by SCUBA divers using a special catch net with a mesh size of $250 \mu \mathrm{m}$, in three replicates in each location. The samples were taken on stations 1 and 3 in the middle of July in 1998, 1999, 2000, and 2001; on station 2 in September 1999 and in the middle of July in 2001 and 2002. An intensive survey of the littoral along the total coastal zone of the Russian part of the eastern Gulf of Finland was conducted in August 2002. At the same time measurements of temperature and oxygen content were conducted with an oxygen meter WTW Oxi 330. Salinity (PSU) was recalculated from conductivity $\left(\right.$ osmol $10^{-3} \mathrm{~L}^{-1}$ ), which was measured with a conductivity meter Dist WP4.

The samples were preserved with $4 \%$ formaldehyde solution and transported to the laboratory in plastic bags. All the collected amphipods were counted, measured, and weighed (wet weight). The density and biomass of the invertebrates were measured as mean value per square metre of bottom taking into account the area of stones and their projective cover of bottom. Also, population characteristics (including fecundity, size-sexual structure) of amphipods were evaluated. All the measured parameters were expressed as mean $\pm \mathrm{SD}$ (standard deviation).

\section{Experimental studies}

In May 2002 specimens of P. robustoides and G. fasciatus were collected from Neva Bay. In laboratory, juveniles were taken from one female of each species. During three months they were reared to adult size and further density increase. The animals were kept initially in large aerated aquaria $(70 \times 40 \mathrm{~cm}$, water depth approximately $15 \mathrm{~cm}$ ). In experiments animals of different size were used (see below).

All experiments (on salinity tolerance, feeding, and species interactions) were conducted under equal conditions. The temperature and day length were close to natural conditions in the littoral of Neva Bay during the mid-summer period: temperatures $20 \pm 0.8^{\circ} \mathrm{C}$ and photoperiod $8 \mathrm{~h}: 16 \mathrm{~h}$ (dark: light). The oxygen concentrations in the water ranged from 7.2 to $8.6 \mathrm{mg} \mathrm{L}^{-1}$. Amphipods were fed on algae (mainly Cladophora glomerata) and dried crustaceans (Daphnia and Gammarus). The salinity of the used water averaged $0.35-0.40$ PSU, which corresponded to the salinity of the water in the locations of mixed populations of both species. All experiments were performed in triplicates. 


\section{Measurements of salinity tolerance in Pontogammarus robustoides}

Water from the Neva River with additions of sea salt up to salinity 0.4 PSU was used as a control and initial salinity at measurements of the upper level of $P$. robustoides tolerance. After two-week acclimation under control conditions, the animals (ten specimens in each replicate) were transferred to vessels with water salinity 1 PSU. Every 10 days the animals were transferred to vessels with water salinity by 1 PSU higher than the previous value (so-called method of "stepwise acclimation"; Khlebovich \& Kondratenkov, 1973). This process was continued until the mortality of animals reached $50 \%$.

We compared also the survival of amphipods at low salinity (0.05-0.4 PSU) and different salt contents of water (water from the Neva River and diluted water from the Neva estuary). Salt contents in these treatments are shown in Table 1. Ten adult animals were held in experimental vessels during 15 days. After the exposure the survival of the animals was evaluated.

In addition, we studied the reproduction potential of amphipods at different water salinities. Acclimated females $(13-15 \mathrm{~mm})$ and males $(15-17 \mathrm{~mm})$ of P. robustoides were kept together (one couple in each vessel) at $0.05,0.1,0.2,1$, 3,5 , and 7 PSU (7 treatments). After fertilization, males were removed and fecund females were regularly examined during 30 days.

\section{Measurements of feeding characteristics}

Before experiments the amphipods were not fed during $12 \mathrm{~h}$ in order to keep their guts empty. One gammarid specimen was put in the experimental vessel $(0.5 \mathrm{~L})$. The exposure time was $24 \mathrm{~h}$. Oligochaetes (Enchytraeus sp.), chironomids (Chironomus sp.), crustaceans (Hyallela azteca), and green alga Cladophora glomerata were used as food items. Nine specimens of $P$. robustoides with body length in the range $6-15.5 \mathrm{~mm}$ were examined for each type of prey. The biomass of prey was around $5 W$, where $W$ is the body weight of the predator. The consumption rate $(C)$ of the gammarids feeding on animal food was measured

Table 1. Salt content (mean $\pm \mathrm{SD}$ ) of the water in the experiments

\begin{tabular}{c|c|c|c|c|r}
\hline Treatment & Experimental water & \multicolumn{4}{|c}{ Salt content of water, $\mathrm{m} \mathrm{L} \mathrm{L}^{-1}$} \\
\cline { 3 - 6 } & & $\mathrm{Na}$ & $\mathrm{K}$ & $\mathrm{Ca}$ & \multicolumn{1}{c}{ Total } \\
\hline \multirow{2}{*}{1} & $\mathrm{NR}$ & $5.1 \pm 0.5$ & $2.0 \pm 0.5$ & $8.5 \pm 2$ & $61 \pm 5$ \\
2 & $\mathrm{NE}$ & $61 \pm 3$ & $17.5 \pm 0.5$ & $37 \pm 2$ & $400 \pm 3$ \\
3 & $1 / 2 \mathrm{NE}+1 / 2 \mathrm{D}$ & $32 \pm 3$ & $10.5 \pm 1$ & $19 \pm 1.5$ & $200 \pm 8$ \\
4 & $1 / 4 \mathrm{NE}+3 / 4 \mathrm{D}$ & $17 \pm 1$ & $5.5 \pm 0.5$ & $10 \pm 2$ & $100 \pm 5$ \\
5 & $1 / 8 \mathrm{NE}+7 / 8 \mathrm{D}$ & $8 \pm 1$ & $2.5 \pm 0.5$ & $7 \pm 1$ & $50 \pm 2$
\end{tabular}

$\mathrm{NE}$ - water from the Neva estuary, NR - water from the Neva River, D - distilled water 
by the method of direct counting and weighing. $C$ values were calculated as the difference between the initial and final quantity (in terms of density and wet weight) of prey during $24 \mathrm{~h}$. The consumption index $(\mathrm{CI})$ was calculated as the ratio of the consumption rate and weight of an animal.

In the case of Cladophora as a food item, 18 specimens of P. robustoides with body length $6-16 \mathrm{~mm}$ and 18 specimens of $G$. fasciatus with body length 5.5-11 mm were examined. As it is known for P. robustoides, individuals less than $6 \mathrm{~mm}$ do not take particles of filamentous algae, they suck out their cellular content (Ioffe \& Maximova, 1968) and consume microperiphyton. For this reason we did not estimate the feeding rates of juveniles. The method of direct weighing was not applicable because of large errors in the case of measuring wet weight of filamentous algae. Therefore, the approximate $C$ values for different size groups of amphipods were calculated as daily production of faeces $(F)$ using an assimilation index 0.6, suggested for plant food by Suschenya (1975). The weight of faeces was measured experimentally. The faeces produced during the exposure was collected, dried at $20^{\circ} \mathrm{C}$, and weighed.

\section{Study of intra- and interspecies interactions of gammarids}

In the series of experiments on interspecies interactions between $G$. fasciatus and $P$. robustoides five experimental groups of gammarids were used with three replicates (Table 2). As the maximum sizes of mature $P$. robustoides $(17-18 \mathrm{~mm}$ ) are much larger than for G. fasciatus $(9-11 \mathrm{~mm})$, selected specimens of both species with equal body size were used in mixed experimental groups. Also, two control treatments with single experimental groups ( 20 individuals each) were used for the measurement of natural death of animals. The experimental containers (glass aquaria of $5 \mathrm{~L}$, water depth approximately $15 \mathrm{~cm}$ ) were large enough to allow animals swim around and escape from potential predators. Each

Table 2. Experimental groups of gammarids

\begin{tabular}{|c|c|c|c|c|}
\hline Treatment & $\begin{array}{l}\text { Experimental } \\
\text { group }\end{array}$ & Species & Body size, mm & Density, ind./vessel \\
\hline \multirow[t]{2}{*}{1} & Single species & 1. G. fasciatus & $3-5$ & 20 \\
\hline & & 2. G. fasciatus & $8-11$ & 20 \\
\hline \multirow[t]{2}{*}{2} & Single species & 1. P. robustoides & $5-8$ & 10 \\
\hline & & 2. P. robustoides & $12-16$ & 20 \\
\hline \multirow[t]{2}{*}{3} & Mixed & 1. G. fasciatus & $6-11$ & 20 \\
\hline & & 2. P. robustoides & $10-12$ & 10 \\
\hline \multirow[t]{2}{*}{4} & Mixed & 1. G. fasciatus & $9-11$ & 20 \\
\hline & & 2. P. robustoides & $5-7$ & 20 \\
\hline \multirow[t]{2}{*}{5} & Mixed & 1. G. fasciatus & $3-5$ & 20 \\
\hline & & 2. P. robustoides & $3-6$ & 20 \\
\hline
\end{tabular}


aquarium was supplied with stone substrates as refugia for animals. The aquaria were aerated constantly. The exposure time was 24 days. Observation notes for each experimental container were made every day in order to record such events as death, moulting, and predatory (cannibalistic) acts. Every three days each replicate was examined in detail, and the remaining animals were counted.

\section{RESULTS}

\section{Establishment and current distribution of Gmelinoides fasciatus and Pontogammarus robustoides in the Gulf of Finland}

Currently G. fasciatus is a widely spread and very abundant species in different parts of the Neva estuary. This Baikalian gammarid penetrated the estuary from lakes of the Karelian Isthmus to which it had been intentionally introduced earlier (Panov \& Berezina, 2002). At present this species is widely spread along the coast of the Neva estuary (Fig. 1). A storm-surge barrier limits its dispersal in the southern part of Neva Bay. In six years after introduction, G. fasciatus became the most numerous species in the littoral zone of the estuary. In 2001-02 its densities varied in the range 500-17 500 ind. $\mathrm{m}^{-2}$ in the stone littoral and Phragmites beds of Neva Bay, and up to 4000 ind. $\mathrm{m}^{-2}$ in the stone littoral with Cladophora mats of the inner estuary.

$P$. robustoides is one of the most recent species discovered in the Gulf of Finland. It was first found in the southern part of Neva Bay in 1999, and in 2000 it was registered in the inner part of the Neva estuary. At present $P$. robustoides spreads everywhere in stone habitats of the southern part of Neva Bay and the northern oligohaline part of the inner Neva estuary (Fig. 1), where it coexists with $G$. fasciatus. For the time being the mean densities of $P$. robustoides populations have not been high (Table 3), but in 2001 they locally exceeded 1500 ind. $\mathrm{m}^{-2}$. The fecundity of $P$. robustoides in the Neva estuary is very high (from 30 to 106 eggs per female with body length in the range 9-14 $\mathrm{mm}$ ), which resulted in its successful establishment in this area in a short period.

Table 3. Densities $\left(N \pm \mathrm{SD}\right.$, ind. $\left.\mathrm{m}^{-2}\right)$ of Pontogammarus robustoides in the eastern Gulf of Finland

\begin{tabular}{l|c|c|c|c|c}
\hline \multicolumn{1}{c|}{ Part } & Habitat & $\begin{array}{c}\text { September } \\
1999\end{array}$ & $\begin{array}{c}\text { July } \\
2000\end{array}$ & $\begin{array}{c}\text { July } \\
2001\end{array}$ & $\begin{array}{c}\text { July } \\
2002\end{array}$ \\
\hline $\begin{array}{l}\text { Neva Bay } \\
\text { Inner Neva estuary }\end{array}$ & $\begin{array}{c}\text { Stone littoral } \\
\text { Stone littoral with Cladophora } \\
\text { mats }\end{array}$ & $40 \pm 16$ & - & $314 \pm 221$ & $509 \pm 443$ \\
- no data & 0 & $8 \pm 8$ & $37 \pm 30.4$ & $360 \pm 232$ \\
&
\end{tabular}




\section{Present state of invertebrate communities in littoral habitats of the Neva estuary}

G. fasciatus has become one of the most abundant species in littoral Phragmites beds. In five years after invasion, the density of the Baikalian amphipod locally reached 17000 ind. $\mathrm{m}^{-2}$. In comparison with 1985, the densities and biomasses of various benthic taxa increased 2-7 fold by the year 2000 (Fig. 2). At the same time, the native amphipod Gammarus lacustris became extinct as a result of G. fasciatus invasion. In 1998 G. fasciatus population contributed for 10-15\% of the total density and biomass of benthic invertebrates during summer. Also, Asellus aquaticus and some species of oligochaetes, leeches, chironomids, and caddisflies dominated in this habitat. The effect of the increasing abundance of benthos during the last decade is likely a result of the intensive development of Phragmites beds in the coastal zone of Neva Bay and enrichment of substrates by detritus from decaying macrophytes, which are suitable food resources for detritivores.

In the stone littoral of Neva Bay, P. robustoides coexists with G. fasciatus and the native species Gammarus pulex. The maximum densities of alien species reached $15000-17000$ ind. $\mathrm{m}^{-2}$. In different microhabitats of the stone littoral the densities of native detritivores were related to the densities of alien gammarids (Fig. 3). At gammarid densities of 500-3000 ind. $\mathrm{m}^{-2}$ the densities of detritivores were 2-3 times as high and varied in the range 1000-7500 ind. $\mathrm{m}^{-2}$. At higher gammarid densities (4000 ind. $\mathrm{m}^{-2}$ and over) the densities of detritivores were

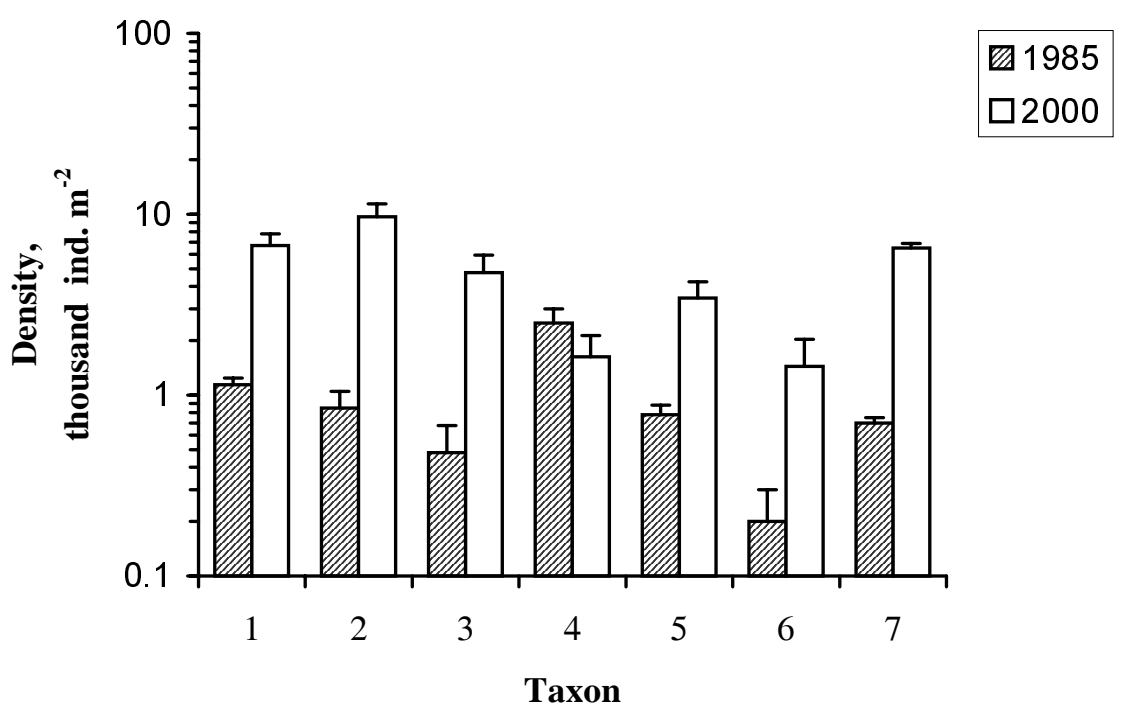

Fig. 2. Densities of different invertebrate taxa in Phragmites beds (station 1) in 1985 and 2000. 1 - Oligochaeta, 2 -Chironomidae, 3 -Gammaridae, 4-Asellus aquaticus, 5 - Trichoptera, 6 - Ephemeroptera, 7 - others. 


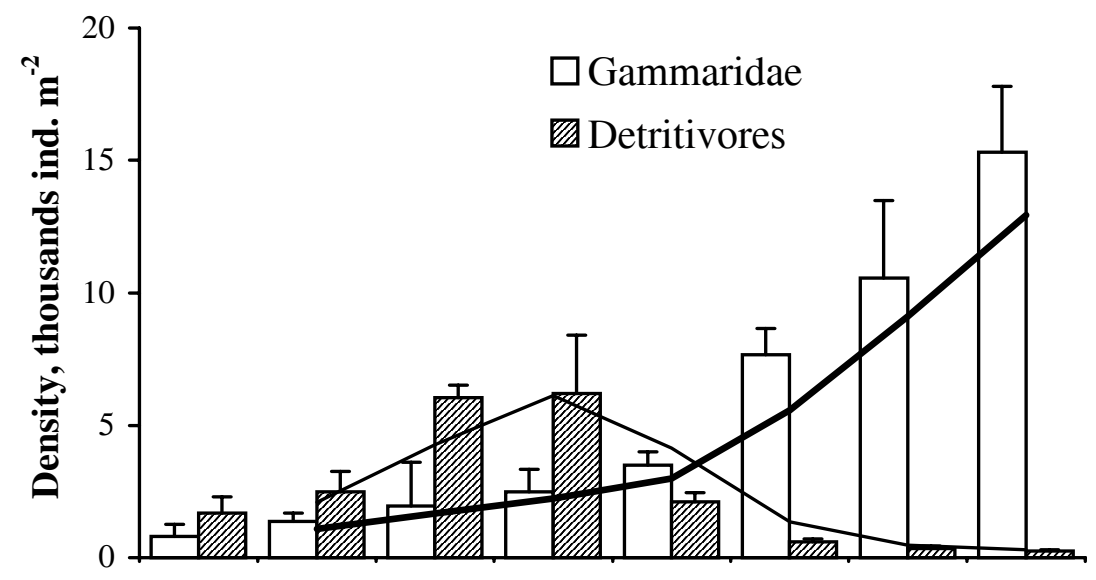

Habitats

Fig. 3. Densities of native detritivores related to increasing densities of alien gammarids in different habitats of the stone littoral in southern Neva Bay (station 2) in July 2001.

below 2000 ind. $\mathrm{m}^{-2}$. At very high densities of alien gammarids $\left(>10000\right.$ ind. $\left.\mathrm{m}^{-2}\right)$ the densities of other benthic invertebrates were very low. Also, the density and biomass of $G$. fasciatus decreased in locations with a high density of $P$. robustoides (Fig. 4). We noted that in locations with high densities of the gammarids the number of body deformities in invertebrates was significant $(40 \%)$, specifically among gammarids of both species with body length $6-9 \mathrm{~mm}$.

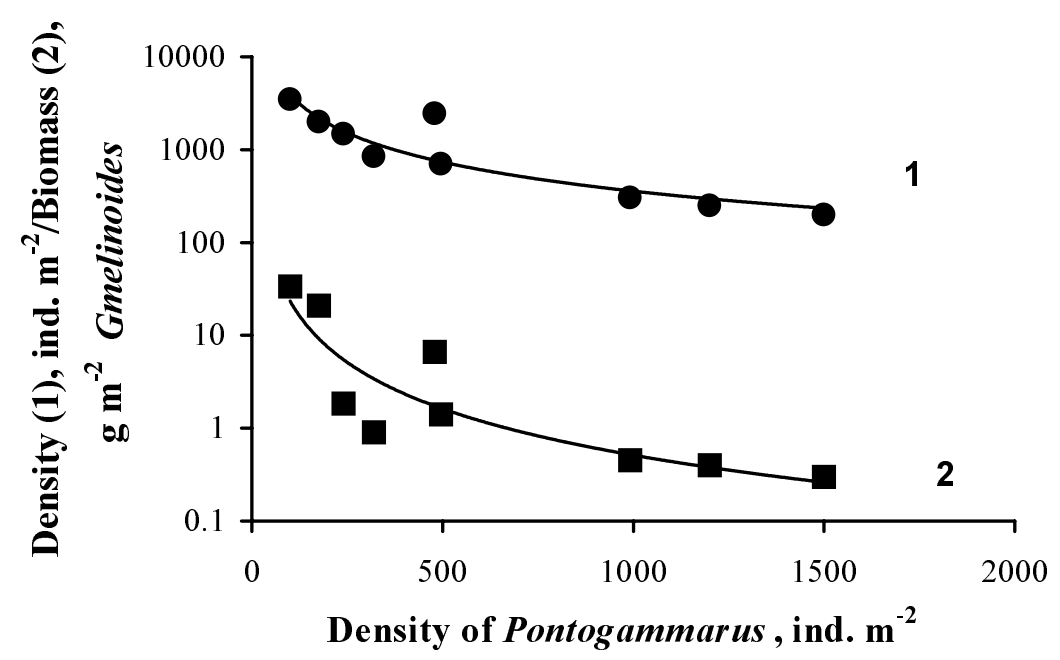

Fig. 4. Densities and biomasses of Gmelinoides depending on the densities of Pontogammarus in locations with coexisting gammarid species (station 2). 
Compared to 2000 the abundances of most invertebrates in Cladophora mats in the inner part of the Neva estuary had increased by 2002 (Fig. 5). The density of alien gammarids ( $G$. fasciatus and P. robustoides) increased about 4-fold. Among benthic invertebrates the herbivore species (chironomids, amphipods, mayflies, and caddisflies) that feed on filamentous algae dominated in 2000 and 2002. This may be a result of improved food resources in the case of high filamentous algae biomass. Biomasses of Cladophora glomerata, the main food for grazers in this habitat, were very high during the last years, reaching $500 \mathrm{~g} \mathrm{~m}^{-2}$ at a depth of $1.5 \mathrm{~m}$ and $150-200 \mathrm{~g} \mathrm{~m}^{-2}$ at $0.5-1 \mathrm{~m}$ (Orlova et al., 1999b).

\section{Salinity tolerance in Pontogammarus robustoides}

Estimation of salinity tolerance in $P$. robustoides revealed high survival and successful reproduction at salinities up to 7 PSU (Fig. 6). Pontogammarus individuals did not survive in the Neva River water (treatment 1, Table 1). They survived at very low salinities (0.05-0.1 PSU) in diluted estuarine water (treatment 5). The mortality of the animals in treatment 1 was $100 \%$ during one week as a result of failed moulting. In treatment 5 their mortality did not exceed $50 \%$. The survival in very strongly diluted estuarine water was possible thanks to higher concentration of $\mathrm{Na}^{+}\left(7-9 \mathrm{mg} \mathrm{L}^{-1}\right)$ than in river water. At salinities higher

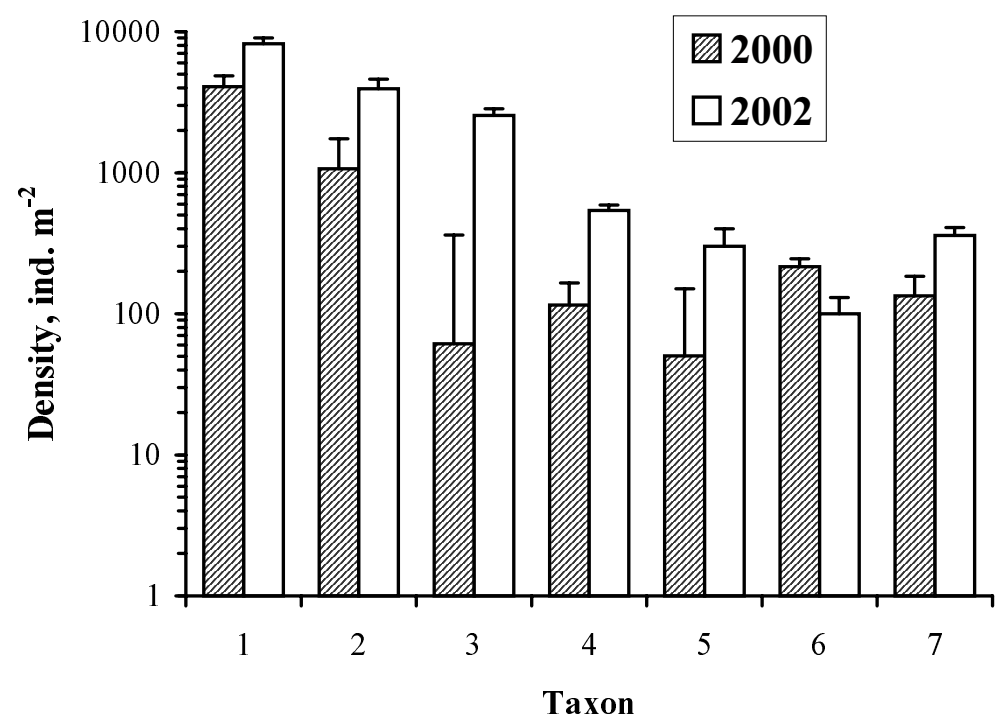

Fig. 5. Densities of different invertebrate taxa in Cladophora mats on stones (station 3) in 2000 and 2002. 1 - Chironomidae, 2 - Gammaridae, 3 - Ephemeroptera, 4 - Trichoptera, 5 - Oligochaeta, 6 - Hirudinea, 7 - others. 


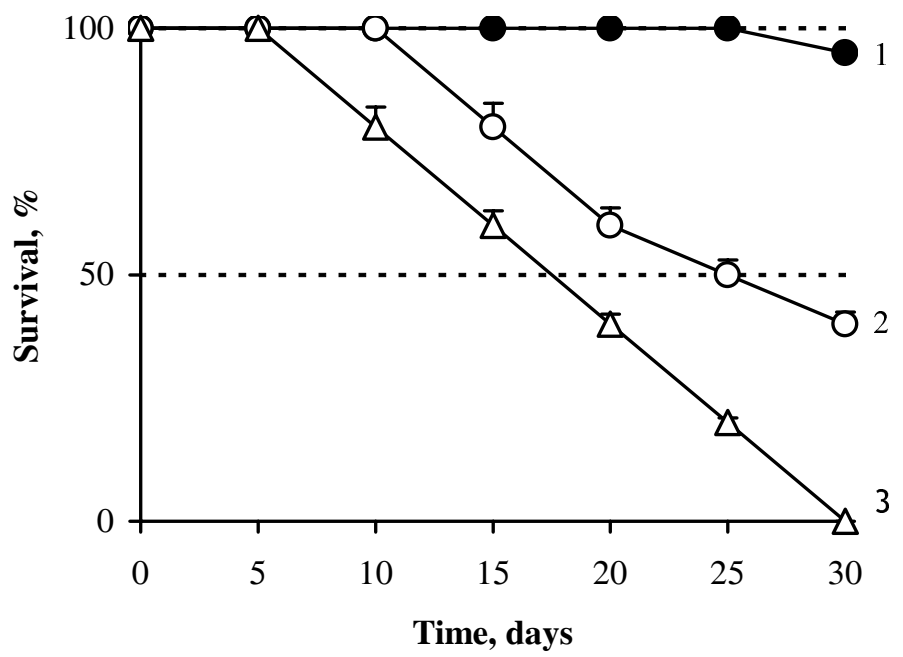

Fig. 6. Salinity resistance in Pontogammarus robustoides in experiments at different salinities. $1-7 \pm 0.6$ PSU, $2-9 \pm 0.7$ PSU, $3-12 \pm 0.5$ PSU.

than 0.1 PSU the survival of the species was high (80-100\%) and did not differ from that in the natural habitat in Neva Bay. Successful reproduction was observed at water salinity from 0.2 to 7 PSU.

\section{Experimental study of gammarid feeding}

The consumption rates of $P$. robustoides were in the range $1-5 \mathrm{mg}$ of algae per day and depended on their body weight. The values for $G$. fasciatus reached $0.2-0.7 \mathrm{mg} \mathrm{day}^{-1}$ (Table 4). Taking into account that the maximum density of P. robustoides in Cladophora mats in the littoral zone (depth $0.2-1 \mathrm{~m}$ ) of the Neva estuary exceeded 500 ind. $\mathrm{m}^{-2}$, we estimated that this population feeding on $C$. glomerata may consume 1-2 g (in aerial dried weight) of the algae per day or 100-200 g during summer. G. fasciatus population with a mean density of 2000 ind. $\mathrm{m}^{-2}$, grazing the algae, is able to consume around $0.5-1.5 \mathrm{~g}$ of Cladophora per day or 45-140 g during summer.

The values of the consumption index $(C I)$ of the gammarids ranged from 20 to $72 \%$ (Table 4), indicating intensive feeding. Our experiments revealed that the gut of $P$. robustoides $(12 \mathrm{~mm})$ was filled with food three times during $12 \mathrm{~h}$ at experimental temperatures. The temperatures corresponded to summer water temperatures in the littoral of the Neva estuary. According to Greze (1977), the time of full empting of the gut of some marine gammarids decreased from $8 \mathrm{~h}$ to $1 \mathrm{~h}$ when water temperature increased from 10 to $23^{\circ} \mathrm{C}$. During this intensive 
Table 4. Feeding rate $(C \pm \mathrm{SD})$, production of faeces $(F \pm \mathrm{SD})$, and consumption index $(C I \pm \mathrm{SD})$ of Pontogammarus robustoides and Gmelinoides fasciatus feeding on Cladophora. $T=20^{\circ} \mathrm{C}$

\begin{tabular}{l|r|c|c|c}
\hline \multicolumn{1}{c}{ Species } & \multicolumn{1}{c}{$L, \mathrm{~mm}$} & $C, \mathrm{mg} \mathrm{day}^{-1}$ & $F, \mathrm{mg} \mathrm{day}^{-1}$ & $C I, \%$ \\
\hline P. robustoides & $7.9 \pm 1.8$ & $1.5 \pm 0.3$ & $0.6 \pm 0.1$ & $68.5 \pm 5.3$ \\
& $12.6 \pm 1.6$ & $2.9 \pm 0.7$ & $1.15 \pm 0.21$ & $29.4 \pm 4.2$ \\
& $15.8 \pm 0.5$ & $4.3 \pm 0.7$ & $1.7 \pm 0.33$ & $22.0 \pm 0.02$ \\
G. fasciatus & $6.3 \pm 0.7$ & $0.27 \pm 0.07$ & $0.12 \pm 0.03$ & $25.5 \pm 1.3$ \\
& $9.0 \pm 1.9$ & $0.6 \pm 0.12$ & $0.18 \pm 0.06$ & $25.0 \pm 3.6$
\end{tabular}

$L$ - body length of gammarids

feeding gammarids produced faeces with partly digested particles. We, as well as other authors (Suschenya, 1975; Greze, 1977), recorded that gammarid juveniles and other detritivores (chironomids, oligochaetes, isopods) consumed such faeces. A G. fasciatus population with a mean density of 2000 ind. $\mathrm{m}^{-2}$ (or a P. robustoides population with a density of 500 ind. $\mathrm{m}^{-2}$ ) foraging on plant food is able to produce around $0.5-1 \mathrm{~g}$ of faeces (in aerial dry weight) per day.

The consumption rates of $P$. robustoides feeding on small oligochaetes, chironomids, and amphipods ranged from 2 to 6 ind. day ${ }^{-1}$ (Table 5) or around 9-20 mg day ${ }^{-1}$ (in wet weight). $C I$ values were the highest (up to 130\%) in the case of gammarids feeding on oligochaetes (Table 5). At such intensity of feeding, the population of this species with a density of 500 ind. $\mathrm{m}^{-2}$ is able to consume 1000-3000 ind. $\mathrm{m}^{-2}$ of small invertebrates per day. Other authors (Kasimov, 1960; Kititsina, 1977) estimated that at higher temperatures of $24-27^{\circ} \mathrm{C}$ (in native water bodies) the feeding intensity of $P$. robustoides is even higher. Preying on small chironomids, one adult specimen of $P$. robustoides consumed approximately 20 chironomids per day, with its $C I$ reaching $135 \%$.

Table 5. Feeding rates $(C \pm \mathrm{SD})$ and consumption index $(C I \pm \mathrm{SD})$ of Pontogammarus robustoides feeding on invertebrates. $T=20^{\circ} \mathrm{C}$

\begin{tabular}{lrr|c|c}
\hline \multicolumn{1}{c}{ Prey } & \multicolumn{1}{c}{$L, \mathrm{~mm}$} & $W, \mathrm{mg}$ & $C$, ind. $\mathrm{m}^{-2}$ day $^{-1}$ & \multicolumn{1}{c}{$C I, \%$} \\
\hline \multirow{4}{*}{ Oligochaeta } & $6.9 \pm 0.2$ & $4.3 \pm 0.4$ & $3.7 \pm 1.4$ & $106.5 \pm 17.7$ \\
& $14.3 \pm 0.3$ & $4.3 \pm 0.4$ & $3.5 \pm 1.5$ & $62 \pm 13.6$ \\
Amphipoda & $8.1 \pm 1.9$ & $3.02 \pm 0.3$ & $5.3 \pm 1.2$ & $63 \pm 12$ \\
& $14.9 \pm 0.7$ & $3.24 \pm 0.4$ & $4.2 \pm 1.3$ & $29 \pm 1$ \\
Chironomidae & $8.6 \pm 0.7$ & $4.5 \pm 0.3$ & $3.6 \pm 0.5$ & $66 \pm 6$ \\
& $12.9 \pm 1.4$ & $4.4 \pm 0.5$ & $3.3 \pm 1.2$ & $32.5 \pm 11$
\end{tabular}

$L$ - body length of predator, $W$ - mean weight of preys 


\section{Experimental study of interspecies interactions between Pontogammarus robustoides and Gmelinoides fasciatus}

The losses of individuals were attributable to predation (cannibalism) and mortality (i.e. death from other causes). The mortality in all experiments did not exceed $10-15 \%$. Cannibalism in G. fasciatus (treatment 1, Table 2) was low, around 2-4 ind. per week or 10-20\%. In the case of G. fasciatus the losses from cannibalism were slightly greater $(5-10 \%)$ than the losses from mortality. Most likely in natural habitats cannibalism will not affect sufficiently G. fasciatus population density. Losses of individuals from cannibalism were more significant for Pontogammarus population (treatment 2) than in the case of G. fasciatus (Fig. 7). The biggest specimens of $P$. robustoides attacked first young individuals $(5-8 \mathrm{~mm})$ and then preyed upon large $(12 \mathrm{~mm})$ moulted specimens.

Figure 8 demonstrates the results of predation of $G$. fasciatus and $P$. robustoides in mixed groups (treatments 3 and 4, Table 2). P. robustoides is a more aggressive and successful predator than G. fasciatus. Large specimens $(9-11 \mathrm{~mm})$ of $G$. fasciatus attacked only moulting specimens of $P$. robustoides. $P$. robustoides often preyed on Gmelinoides specimens with different size (treatment 4), preferring larger individuals to smaller ones. While the predation intensity for $P$. robustoides averaged $10.3 \pm 0.5$ ind. per week, for $G$. fasciatus it was significantly lower (3.6 \pm 0.5 ind. per week). In mixed groups with juveniles of both species (treatment 5, Table 2) more rapid growth of $P$. robustoides than G. fasciatus was revealed. Switch of $P$. robustoides to intraguild predation was recorded in 8 days for specimens reaching body length of $7 \mathrm{~mm}$. During 12-18 days losses of G. fasciatus amounted to $70-85 \%$.

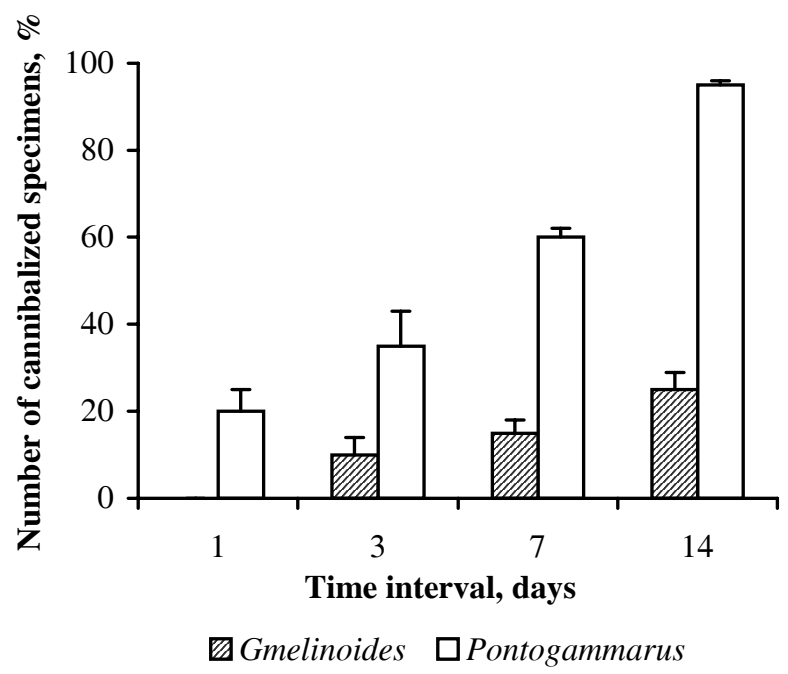

Fig. 7. Cannibalism in experimental single-species populations (treatments 1 and 2) of Gmelinoides fasciatus and Pontogammarus robustoides. 


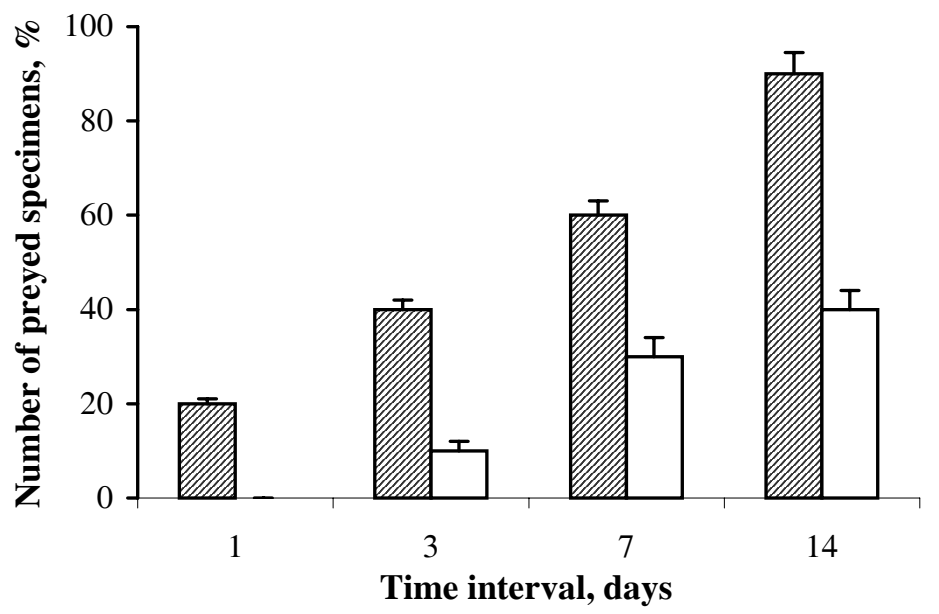

Ⓖmelinoides $\square$ Pontogammarus

Fig. 8. Predation in experimental mixed-species populations (treatments 3 and 4) of Gmelinoides fasciatus and Pontogammarus robustoides.

\section{DISCUSSION}

\section{Distribution of alien gammarids in the Gulf of Finland}

Intentional introduction is the main vector that contributed to the expansion of both G. fasciatus and P. robustoides in the Baltic Sea basin from native regions. The invasion route of the Baikalian gammarid G. fasciatus to the Gulf of Finland was revealed earlier (Panov \& Berezina, 2002), but the route of $P$. robustoides is not clear. The original distribution areas of $P$. robustoides encompassed offshore areas of the Caspian and Black seas and lower reaches of some rivers (Dedju, 1980; Jazdzewski, 1980; Jazdzewski \& Konopacka, 2000). In the 1950s-60s specimens of $P$. robustoides were intentionally transferred from Dniepr Reservoir to Kaunas Reservoir (Gasiunas, 1972). After a self-reproducing population was established in the reservoir during 1965-69, this water body was used as a donor area for intentional introductions into other inland waters including lakes of Leningrad Region (Gasiunas, 1972; Lazauskene et al., 1995). The results of these introductions are not known. However, we can suppose that these introductions were the source of Pontogammarus population's further expansion in the Neva estuary. Our intensive survey in the eastern part of the Gulf of Finland showed absence of $P$. robustoides outside the inner Neva estuary. This fact supports the hypothesis that the species penetrated the Gulf of Finland basin from inland waters, and contradicts the possibility of a "marine route", i.e. through dispersal 
along the coastal zone from the southern part of the Baltic Sea. Also, introduction of $P$. robustoides to the Neva estuary may have occurred by discharge of ballast water originating from the southern Baltic Sea.

\section{Salinity tolerance in the alien gammarids}

As a rule, P. robustoides prefers lower salinity and is the most abundant species in the oligohaline zone of invaded estuaries in the southern parts of the Baltic Sea (Jazdzewski \& Konopacka, 2000). In native areas P. robustoides is spread in shallow freshwater and oligohaline zones, but does not live in the mesohaline zone (Mordukhai-Boltovskoi, 1960). Earlier P. robustoides was registered in some locations of the Curonian Lagoon (near Klaipeda, Lithuania) with water salinity of 7 PSU (Gasiunas, 1972).

Sexually mature specimens of G. fasciatus tolerate salinities of 4-6 PSU, which is the upper limit for this species (Berezina et al., 2001). Experimental studies showed that the salinity tolerance in $G$. fasciatus decreased at high water temperatures. Temperatures below $22^{\circ} \mathrm{C}$ are more suitable for the acclimatization of adult $G$. fasciatus in oligohaline habitats (up to 5 PSU), and this species will not be able to colonize brackish-water areas with high summer temperatures (Berezina \& Panov, 2003). However, establishment of G. fasciatus within the eastern Gulf of Finland will be limited by salinities above 2 PSU because of unsuccessful reproduction (Berezina et al., 2001).

The upper level of salinity resistance in P. robustoides and G. fasciatus approximately corresponds to the salinity in the coastal zone of the Baltic Sea. In the future, expansion of both species from the Neva estuary to different coastal habitats of the Baltic Sea is very likely by discharge of ballast water or dispersal along the coastal zone.

Low concentrations of chloride salts will limit the establishment of $P$. robustoides. Estuarine salt content of water with $\mathrm{Na}^{+}$concentration not less than $17 \mathrm{mg} \mathrm{L}^{-1}$ is needed for successful reproduction in P. robustoides. Our data suggest that expansion of $P$. robustoides to the northern part of Neva Bay is not possible because of low salinity due to the strong influence of the Neva River water with a low $\mathrm{Na}^{+}$concentration. Calcium concentration $\left(\mathrm{Ca}^{2+}\right)$ of $3 \mathrm{mg} \mathrm{L}^{-1}$ in water will limit the moulting in $G$. fasciatus; but even at $5-7 \mathrm{mg} \mathrm{L}^{-1} \mathrm{Ca}^{2+}$ in water the density of $G$. fasciatus is low (Ioffe \& Nilova, 1975; Berezina, 2003a). These values are likely natural barriers for the dispersal of this species in fresh water bodies of the Baltic Sea basin.

\section{Experimental study of gammarid feeding}

Filamentous algae (Cladophora sp.) are favourite food for P. robustoides in different water bodies, for instance in the northern Caspian Sea (Briskina, 1952), the Don estuary (Ioffe \& Maximova, 1968), Lithuanian lakes (Gasiunas, 1975), 
and also for G. fasciatus in lakes of the Baikalian region (Mekhanikova, 2000). Consuming mainly filamentous algae, these species may influence the Cladophora biomass in some locations of the Neva estuary.

The main item in the diet of Gmelinoides in reed beds of the Neva estuary is filamentous algae developed on the underwater Phragmites stems and detritus (Berezina, 2003b). Animal food plays a significant (30-50\%) role in the diet of gammarids with body length $7.5 \mathrm{~mm}$ and over. A peculiarity of the population dynamics of G. fasciatus in Phragmites beds in 1998-2001 was domination (70-90\%) of juveniles and females with body length less than $7 \mathrm{~mm}$ during the summer. Therefore, the effect of Gmelinoides predation on benthic organisms in the case of large food resources available is negligible. The same effect of the gammarids was recorded in Cladophora mats on stones. This may be a result of available food resources. At the same time, populations of G. fasciatus and $P$. robustoides with high densities foraging on Cladophora or other food of plant origin are able to produce significant amounts of faeces, which enrich sediments with organic matter. Thus, the amphipods play an important role in the transformation of organic matter, which results in its increasing availability for benthic detritivores.

If food resources are poor abundant mature gammarids will switch to active predation and may adversely affect other animals, including their own juveniles and moulted specimens. It was experimentally revealed that $P$. robustoides is an active predator and able to kill a significant number of small invertebrates. This may result in a decrease in species densities and richness. We suggest that the predation of the gammarids will be especially strong in case of plant food limitation in such habitats as the open stone littoral of Neva Bay.

\section{Experimental study of interspecies interactions between Pontogammarus robustoides and Gmelinoides fasciatus}

The results obtained support the hypothesis that intraguild predation is the primary mechanism of strong decrease in the abundance of G. fasciatus in locations with coexisting gammarid species. Because of predation the abundance of $G$. fasciatus will continue to decrease, which may result in displacement of this species in locations with $P$. robustoides. At the same time, the wide environmental tolerance and short life cycle of G. fasciatus as well as its ability to produce up to 6-8 generations during a season (Panov \& Berezina, 2002) may result in successful coexistence of $G$. fasciatus and P. robustoides in the Neva estuary. Intraguild predation and higher resistance to environment in invaders caused the disappearance of the native gammarid Gammarus lacustris from Phragmites beds of Neva Bay after the invasion of G. fasciatus in the 1980s (Berezina \& Panov, 2003).

Dick \& Platvoet (2000) showed that Dikerogammarus villosus is rapidly eliminating the native Gammarus duebeni and the introduced Gammarus tigrinus from aquatic ecosystems in The Netherlands. In these cases and in the case of 
replacement of G. duebeni by an invader Gammarus pulex, it was experimentally demonstrated that interspecies predation rather than food competition or environmental tolerance was the main reason of the replacement (Dick et al., 1999). Discussing the replacement mechanisms, we would like to stress that this phenomenon is usual in the case of malacostracan crustaceans of different origin. Similar antagonistic relationships were noted between all the Ponto-Caspian species and freshwater gammarids (Martynov, 1932; Mordukhai-Boltovskoi, 1960), as well as between Gammarus fasciatus and G. pulex, G. pulex and G. lacustris (Dedju, 1980), G. duebeni and G. pulex (Dick et al., 1994), G. duebeni and G. salinus (Kinne, 1954). Also, in some cases the new species may coexist with the natives and earlier established gammarids, as do G. tigrinus and P. robustoides in the Szczecin Lagoon (Jazdzewski \& Konopacka, 2002).

\section{Possible effects of alien established gammarids on littoral communities}

Our study and data of other authors indicate that after establishment the alien amphipods $P$. robustoides and $G$. fasciatus may influence littoral communities of the Neva estuary. We revealed four possible effects that might be more noticeable in littoral communities during further increase in alien gammarids' density. First, consuming filamentous algae, the established species may reduce the Cladophora biomass in the littoral of the Neva estuary. For example, Gasiunas (1975) showed that an established population of $P$. robustoides with densities up to 4980 ind. $\mathrm{m}^{-2}$, feeding on Cladophora, contributed to the disappearance of the algae in the littoral zone of some lakes of Lithuania in five years after introduction.

Secondly, establishment of alien gammarids in Phragmites beds and Cladophora mats may be examples of favourable impacts on food webs as they transform organic matter for other trophic levels. In other studies, it was also demonstrated that alien species (including the amphipod Corophium curvispinum) play a significant role in energy mediation in the ecosystem (Kelleher et al., 2000).

Thirdly, predation on small benthic organisms may decrease their density and species diversity in the invertebrate community. This phenomenon is often considered the main negative impact observed in a community as an effect of established amphipods. In the stone littoral in Neva Bay, predation of the invasive amphipod $P$. robustoides on benthic organisms was the main mechanism that decreased invertebrate density. It is likely that an abundant population of invasive gammarids may exhaust food resources in some locations. In that case the decrease in the abundance of invertebrate species may be a result of predation as well as of competition for food. It is important that at food exhaustion in a littoral community the density of invasive gammarids may remain high due to their high fecundity and ability to switch to intraguild predation (or cannibalism).

Finally, intraguild predation and competition for food may result in changes in the population structure, decrease of the abundance, and even disappearance of some gammarid species (native or alien) in the case of coexisting populations. 


\section{CONCLUSIONS}

Two species of gammaridean amphipods, Gmelinoides fasciatus and Pontogammarus robustoides, invaded the eastern Gulf of Finland in the 1990s. During several years these species established self-reproducing populations in the littoral zone of Neva Bay and along the northern coast of the inner Neva estuary. Establishment of alien gammarids resulted in significant changes in littoral communities of the estuary. The gammarids, consuming large amounts of detritus and benthic algae, contribute to intensification of transformation of organic matter and enrichment of bottom substrates with food resources available for other trophic levels. In locations with high densities of $P$. robustoides and G. fasciatus, gammarids may reduce the Cladophora biomass by intensive grazing. Predation by the gammarids is the main mechanism of regulation of invertebrate abundance and complete replacement of some native or earlier established alien species in littoral communities. The magnitude of these effects depends on the types of habitats, gammarid density, and amount of food resources in the habitat.

\section{ACKNOWLEDGEMENTS}

We thank two anonymous referees for their valuable comments on the manuscript, and Nick Kovaltchouk, Natalie Zaporozhets, and Svjatoslav Klimentenok for assistance with the sampling. The study was supported by the Russian Federal Contract No. 43.073.1.1.2511 and grants from the Presidium of the Russian Academy of Sciences on Biodiversity Conservation, the Russian Foundation for Fundamental Research (No. 1634.2003.4), and Maj and Tor Nessling Foundation.

\section{REFERENCES}

Berezina, N. A. 2003a. Tolerance in freshwater invertebrates to changes in water salinity. Russ. J. Ecol., 34(4), 261-266.

Berezina, N. A. 2003b. Seasonal dynamics and fecundity of Gmelinoides fasciatus (Stebbing 1899) (Amphipoda: Crustacea) in macrophyte zone of northern Neva Bay (Gulf of Finland, Baltic Sea). Zool. Zh., in press (in Russian).

Berezina, N. A. \& Panov, V. E. 2003. Distribution, population structure and salinity resistance in the invasive amphipod Gmelinoides fasciatus (Stebbing) in the Neva Estuary (Gulf of Finland, Baltic Sea). Hydrobiologia, in press.

Berezina, N. A., Khlebovich, V. V., Panov, V. E. \& Zaporozhets, N. V. 2001. Salinity resistance in the amphipod Gmelinoides fasciatus (Stebb.), introduced into the Gulf of Finland (Baltic Sea) basin. Dokl. Acad. Nauk, 379(3), 414-416 (in Russian). 
Briskina, M. M. 1952. Diet of benthic invertebrates in northern part of the Caspian Sea. Dokl. VNIRO, 1, 121-126 (in Russian).

Bij de Vaate, A., Jazdzewski, K., Ketelaars, H. A. M., Gollasch, S. \& Van der Velde, G. 2002. Geographical patterns in range extension of Ponto-Caspian macroinvertebrate species in Europe. Can. J. Fish. Aquat. Sci., 59, 1159-1174.

Dedju, I. I. 1980. Amphipods of Fresh and Brackish Waters of South-West of USSR. Shtiintsa, Kishinev (in Russian).

Dennert, H. G. 1974. Tolerance differences and interspecific competition in three members of the amphipod genus Gammarus. Bijdr. Dierk., 44(1), 83-99.

Dick, J. T. A. \& Platvoet, D. 2000. Invading predatory crustacean Dikerogammarus villosus eliminates both native and exotic species. Proc. R. Soc. Lond., 267, 977-983.

Dick, J. T. A., Elwood, R. W. \& Montgomery, W. I. 1994. Range expansion of the alien amphipod Gammarus pulex in the River Lagan. Ir. Nat. J., 23, 403-404.

Dick, J. T. A., Montgomery, W. I. \& Elwood, R. W. 1999. Intraguild predation may explain an amphipod replacement: evidence from laboratory populations. J. Zool. Lond., 249, 463-468.

Elton, C. S. 1958. The Ecology of Invasions by Animals and Plants. Methuen, London.

Gasiunas, I. 1972. Enrichment of food resources of water bodies of Lithuania by acclimatized crustaceans from Caspian Sea complex. In On the Breeding of Fish and Crustaceans in the Water Bodies of Lithuania (Virbitskas, J. ed.), pp. 57-68. Vilnius (in Russian).

Gasiunas, I. 1975. Peracarida from Lake Dusya (Baltic Sea basin). Gidrobiol. Zh., 11(1), 46-50 (in Russian).

Greze, I. I. 1977. Amphipods of Black Sea and Their Biology. Naukova Dumka, Kiev (in Russian).

Holdich, D. M., Rogers, W. D. \& Reynolds, J. D. 1999. Native and alien crayfish in the British Isles. In Crayfish in Europe as Alien Species. How to Make the Best of a Bad Situation (Gherardi, F. \& Holdich, D. M., eds.), pp. 221-235. Balkema, Rotterdam, Brookfield.

Ioffe, T. I. \& Maximova, L. P. 1968. Biology of some crustaceans used for acclimatization into reservoirs. Izvest. GosNIORKH, 67, 87-104 (in Russian).

Ioffe, T. I. \& Nilova, O. I. 1975. Experiments on introductions of Baikalian gammarids in lakes of North-West. Izvest. GosNIORKH, 103, 11-16 (in Russian).

Jazdzewski, K. 1980. Range expansions of some gammaridean species in European inland waters caused by human activity. Crustaceana Suppl., 6, 84-106.

Jazdzewski, K. \& Konopacka, A. 2000. Immigration history and present distribution of alien crustaceans in Polish waters. Crustacean Issues, 12, 55-64.

Jazdzewski, K. \& Konopacka, A. 2002. Invasive Ponto-Caspian species in waters of the Vistula and Oder basins and the southern Baltic Sea. In Invasive Aquatic Species of Europe Distribution, Impact and Management (Leppäkoski, E., Gollasch, S. \& Olenin, S., eds.), pp. 384-398. Kluwer Acad. Publ., Dordrecht, Boston, London.

Kasimov, A. G. 1960. Biology of amphipod Pontogammarus robustoides (Grimm). Zool. Zh., 39(8), 1151-1155 (in Russian).

Kelleher, B., Van der Velde, G., Giller, P. S. \& Bij de Vaate, A. 2000. Dominant role of exotic invertebrates, mainly Crustacea, in diets of fish in the lower Rhine. Crustacean Issues, 12, 35-46.

Khlebovich, V. V. \& Kondratenkov, A. P. 1973. Stepwise acclimation - a method for estimating the potential euryhalinity of the gastropod Hydrobia ulvae. Mar. Biol., 18, 6-8.

Kinne, O. 1954. Interspezifische Sterilpaarung als konkurren-zoecologisher Factor bei Gammariden (Crustacea, Peracarida). Naturwissenschaften, 18, 434-435. 
Kititsina, L. A. 1977. Feeding rate of amphipod Pontogammarus robustoides at different temperatures. Gidrobiol. Zh., 11(1), 51-55 (in Russian).

Korelyakova, I. L. 1997. Macrophytes of Eastern Part of the Gulf of Finland. Nauka, St. Petersburg (in Russian).

Lazauskene, L. A., Vainotis, G. I. \& Razinkov, A. Y. 1995. Results of acclimatization of invertebrates in the Baltic region. In Results of Acclimatization of Aquatic Organisms (Kuderski, L. A., ed.), pp. 167-178. Izd. GosNIORKH, Sankt-Petersburg (in Russian).

Leppäkoski, E. \& Olenin, S. 2000. Non-native species and rates of spread: lessons from the brackish Baltic Sea. Biol. Invas., 2, 151-163.

Martynov, A. V. 1932. Studies of freshwater fauna of Black Sea coast of Caucasian. I. Amphipoda. Tr. Zool. Inst. AN USSR, 1, 73-98 (in Russian).

Mekhanikova, I. V. 2000. Morphological and ecological adaptations of Baikalian amphipod Gmelinoides fasciatus to environmental conditions of different water bodies. Tr. Biol. Pochv. Fak. Irkutsk. Univ., 3, 104-114 (in Russian).

Mordukhai-Boltovskoi, F. D. 1960. Caspian Fauna in the Azov-Black Seas Basin. Izd. Acad. Nauk USSR, Moskva (in Russian).

Nyström, P., Brönmark, C. \& Graneli, W. 1999. Influence of an exotic and native crayfish species on littoral benthic community. Oikos, 85, 545-553.

Orlova, M. I., Panov, V. E., Krylov, P. I., Telesh, I. V. \& Khlebovich, V. V. 1999a. Changes in plankton and benthic communities in the eastern Gulf of Finland, associated with biological invasions. Proc. Zool. Inst., 279, 305-325 (in Russian).

Orlova, M. I., Anokhina, L. E., Panov, V. E., Nekrasov, A. V. \& Klimentenok, S. N. 1999b. Preliminary environmental state assessment for littoral zone in Resort District of St. Petersburg. Balt. Float Univ. Res. Bull., 3, 37-42.

Panov, V. E. \& Berezina, N. A. 2002. Invasion history, biology and impacts of the Baikalian amphipod Gmelinoides fasciatus. In Invasive Aquatic Species of Europe - Distribution, Impact and Management (Leppäkoski, E., Gollasch, S. \& Olenin, S., eds.), pp. 96-103. Kluwer Acad. Publ., Dordrecht, Boston, London.

Panov, V. E. \& Pavlov, A. M. 1986. Method of counting of aquatic invertebrates in beds of bulrush and reed. Gidrobiol. Zh., 22(6), 87-88 (in Russian).

Panov, V. E., Krylov, P. I. \& Telesh, I. V. 1999. The St. Petersburg harbour profile. In Initial Risk Assessment of Alien Species in Nordic Coastal Waters (Gollasch, S. \& Leppäkoski, E., eds.), pp. 225-244. Nordic Council of Ministers, Copenhagen.

Panov, V. E., Alimov, A. F., Golubkov, S. M., Orlova, M. I. \& Telesh, I. V. 2002. Environmental problems and challenges for the coastal zone management in the Neva estuary (eastern Gulf of Finland). In Baltic Coastal Ecosystems: Structure, Function and Coastal Zone Management (Schernewski, G. \& Schiewer, U., eds.), pp. 171-184. CEEDES-Ser., Springer, Berlin.

Suschenya, L. M. 1975. Quantitative Characteristics of Feeding of Crustaceans. Nauka i Tekhnika, Minsk (in Russian).

Van der Velde, G., Rajagopal, S., Kelleher, B., Musko, I. B. \& Bij de Vaate, A. 1999. Ecological impact of crustacean invaders: general considerations and examples from the Rhine River. In The Bioversity Crisis and Crustacea: Proceedings of the Fourth Intern. Crustacean Congress (Carel von Vaupel Klein, J. \& Schram, F. R., eds.), pp. 3-33. Balkema, Rotterdam, Brookfield.

Westman, K. 2002. Alien crayfish in Europe: negative and positive impacts and interactions with native crayfish. In Invasive Aquatic Species of Europe - Distribution, Impact and Management (Leppäkoski, E., Gollasch, S. \& Olenin, S., eds.), pp. 76-95. Kluwer Acad. Publ., Dordrecht, Boston, London. 


\title{
Kahe uue kirpvähiliigi invasioon Soome lahte ja nende mõju rannikumere kooslustele
}

\begin{abstract}
Nadya A. Berezina ja Vadim E. Panov
Viimase aastakümne jooksul on Soome lahest leitud kaks uut kirpvähiliiki: Gmelinoides fasciatus (Stebb.) ja Pontogammarus robustoides (Sars). Käesolevas töös on uuritud mainitud liikide levikut ja arvukust ning nende mõju rannikumere kooslustele Neeva jõe suudmes aastatel 1998-2002 kolmes elupaigatüübis: Phragmites australis'e kooslus, avatud kivine põhi ning Cladophora glomerata matid kivisel põhjal. Eksperimentaalselt hinnati niitjatest vetikatest ja põhjaselgrootutest toituvate tulnukliikide toitumise määra. Uuritavad võõrliigid tarbivad intensiivselt taimset päritolu toitu ( $C$. glomerata ja $P$. australis'e juured ning jäänused), nende väljaheidete hulk suureneb ja seetõttu rohkeneb detriidist toituvatele põhjaselgrootutele kättesaadav orgaanilise aine hulk. Samal ajal söövad tulnukliigid põhjaselgrootuid, see vähendab viimaste arvukust. Kahe eeltoodud protsessi ulatuse määrab ära nii võõrliikide tihedus kui ka elupaigatüüp.
\end{abstract}

